\title{
Motivasi Wisatawan Mancanegara Dalam Kegiatan Trekking Di Bukit Lawang, Kabupaten Langkat Sumatera Utara.
}

\author{
Hetty Claudia \\ Politeknik Pariwisata Medan \\ E-mail: hetty.claudia@gmail.com
}

\begin{abstract}
Bukit Lawang is a part of the area of Gunung Leuser National Park which has a very beautiful natural wealth, richness of flora and fauna and orangutan rehabilitation centers. Motivation is an impulse that arises in someone to do something based on the needs of itself to achieve a certain goal. One of the tourist attractions that can be done and favored by tourists, especially foreign tourists, is trekking. However, the attraction of trekking in Bukit Lawang still cannot attract foreign tourist visits to visit Bukit Lawang, which is marked by a decrease in tourist visit data to Bukit Lawang. The study was conducted at Bukit Lawang Langkat Regency, North Sumatra. The method used in this research is descriptive method. Data collection techniques carried out in this study was observation, literature study, and questionnaire. Based on observations and data management showed that the manager of Bukit Lawang in packing a trekking tour package was still less than the variation / diversity of trekking activities starting from adding trekking routes and variations in duration of trekking packages, so that the motivational factors of tourists in carrying out trekking activities both pull and push factor owned by tourists are not too high. So that it will affect the satisfaction of foreign tourists who carry out trekking activities.
\end{abstract}

Keywords: Attractions, motivation, tourist satisfaction

Abstrak - Bukit Lawang adalah sebagian kawasan dari Taman Nasional Gunung Leuser yang memiliki kekayaan alam yang sangat indah, kekayaan flora dan fauna dan pusat rehabilitasi orangutan.Motivasi merupakan dorongan yang timbul pada seseorang untuk melakukan sesuatu yang didasari atas kebutuhan dalam diri untuk mencapai suatu tujuan tertentu.Salah satu atraksi wisata yang bisa dilakukan dan digemari oleh wisatawan terutama wisatawan mancanegara adalah trekking.Namun, atraksi trekking diBukit Lawang masih belum bisa menarik kunjungan wisatawan mancanegara datang berkunjung ke Bukit Lawang, ditandai dengan penurunan data kunjungan wisatawan ke Bukit Lawang.Penelitian dilakukan di Bukit Lawang Kabupaten Langkat, Sumatera Utara.Metode yang digunakan dalam penelitian ini adalah metode deskriptif. Teknik pengumpulan data yang dilakukan dalam penelitian ini berupa observasi, studi kepustakaan, dan kuesioner.Berdasarkan hasil observasi dan pengelolaan data menunjukkan bahwa pihak pengelola Bukit Lawang dalam mengemas paket wisata trekking masih kurang maksimal baik dari variasi/keragaman kegiatan trekking mulai dari penambahan rute trekking dan variasi durasi paket trekking, sehingga faktor-faktor motivasi wisatawan dalam melakukan kegiatan trekking baik pull and pushfactor yang dimiliki oleh wisatawan tidak terlalu tinggi. Sehingga akan berpengaruh pada kepuasan wisatawan mancanegara yang melakukan kegiatan trekking.

Kata Kunci :Atraksi, motivasi, Kepuasan wisatawan

\subsection{Latar Belakang Masalah}

Negara Indonesia merupakan negara kepulauan yang memiliki kurang lebih 17.504 pulau, yang dihuni oleh 1.340 suku yang mendiami 34 provinsi. Hal ini menjadi salah satu indikator bahwa Indonesia memiliki potensi yang besar dibidang pariwisata. Hal ini menjadikan pariwisata menjadi penghasil devisa negara terbesar ke-3 setelah gas bumi dan kelapa sawit. Dan tahun 2019 pemerintah mencanangkan bahwa pariwisata akan menjadi penghasil devisa terbesar bagi Indonesia. Hal ini tidak akan lepas dari kekayaan alam yang terbentang dari Sabang Merauke juga kekayaan budaya yang beragam, salah satunya adalah pulau
Sumatera. Sumatera adalah salah satu pulau yang terdapat di Indonesia, Sumatera adalah pulau keenam terbesardi dunia yang terletak di Indonesia, dengan luas 443.065,8 $\mathrm{km}^{2}$ dan jumlah penduduk lebih 91.803 .000 jiwa .lbukota Provinsi Sumatera Utara adalah Medan yang juga merupakan pusat pemerintahan dan pusat bisnis provinsi Sumatera Utara, hal ini menjadikan Medan sebagai kota terbesar ke 3 (tiga) di Indonesia. Sumber daya alam tropis yang kaya, panorama yang indah, dan hutan hujan tropis pada Bukit Lawang di Taman Nasional Gunung Leuser serta letaknya yang geografis. Sumatera Utara relative dekat dengan Malaysia dan Singapura membuat provinsi ini 
menjadi tujuan yang popular bagi wisatawan mancanegara dan nusantara.

Berbagai motivasi yang dimiliki oleh wisatawan baik domestik dan mancanegara yang datang berkunjung ke suatu Bukit Lawang, dimana tidak hanya faktor pendorong (push factor) yang harus dimiliki oleh wisatawan sehingga memutuskan untuk berkunjung ke Bukit Lawang, melainkan harus terdapat faktor penarik (pull factor) yang dimiliki oleh Bukit Lawang sebagai objek wisata, agar wisatawan baik domestik ataupun mancanegara untuk mengunjungi daerah tersebut.

Bukit Lawang merupakan salah satu kawasan ekowisata di Sumatera Utara, terletak di Kecamatan Bahorok, Kabupaten Langkat.Kawasan Bukit Lawang terletak didalam Taman Nasional Gunung Leuser. Taman nasional ini mengambil nama dari Gunung Leuser yang menjulang tinggi dengan ketinggian 3.404 meter diatas permukaan laut. Taman nasional ini meliputi ekosistem asli dari pantai sampai pegunungan tinggi yang diliputi oleh hutan lebat khas hujan tropis, dikelola dengan sistem zonasi yang dimanfaatkan untuk tujuan penelitian, ilmu pengetahuan, pendidikan, menunjang budidaya, pariwisata, dan rekreasi.Bukit Lawang secara harfiah berarti "pintu ke bukit", dimana daya tarik utama Bukit Lawang adalah orangutan, trekking dan tubing.Hal ini menjadi faktor penarik, yang membuat wisatawan tertarik untuk mengunjungi Bukit Lawang. Namun, hal ini tidak seiring dengan tingkat kunjungan wisatawan, menurut Sasli, Pranoto, 2017, http://www.medanbisnisdaily.com/news/online/ read/2017/11/09/12496/jalan_rusak_hambat_I aju_wisatawan_ke_tangkahan_dan_bukit_lawa ng, 27 November 2017.

Tingkat kunjungan wisatawan dari tahun 2015 ke 2016 menurun drastis.Tahun 2015 terdapat kunjungan wisatawan mancanegara sejumlah 3.495, wisatawan domestik sejumlah 47.139. Tahun 2016 terdapat kunjungan wisatawan manca negara sejumlah 4.885, wisatawan domestik sejumlah 13.715terlihat bahwa terjadi penurunan data kunjungan wisatawan ke Bukit Lawang. Oleh karena itu berdasarkan latar belakang di atas, penulis mengangkat judul Motivasi Wisatawan Mancanegara dalam Kegiatan Trekking di Bukit Lawang, Kabupaten Langkat Sumatera Utara. Adapun tujuan penelitian ini adalah sebagai referensi bagi pihak pengelola Bukit Lawang untuk meningkatkan kualitas kegiatan trekking, sehingga dapat meningkatkan motivasi wisatawan untuk berkunjung.

\subsection{Tinjauan Pustaka \\ 2.1.1. Tinjauan Umum tentang Objek Wisata Bukit Lawang}

Bukit Lawang merupakan desa sekitar hutan yang membukit. Letak geografis desa adalah $255^{\prime}-4^{\circ} 05^{\prime} \mathrm{LU}$ dan $98^{\circ} 30^{\prime} \mathrm{BT}$, dengan luas desa $192.660 \mathrm{Ha}$. Untuk mencapai desa perkawasan Bukit Lawang jarak yang harus ditempuh adalah $11 \mathrm{~km}$ dari Kecamatan Bahorok. Sedangkan dari Medan menuju Bukit Lawang memakan waktu perjalanan adalah sekitar \pm 3 jam. Pada tahun 1973 hingga 2001 sebuah organisasi Swiss mendirikan pusat rehabilitas Orangutan di Bukit Lawang, 229 Orangutan bekas peliharaan yang disita dari perdagangan satwa sudah direhabilitasi di lokasi ini. Tujuan pusat ini adalah untuk merehabilitasi Orangutan yang dilepaskan dari penangkaran. Dengan kedatangan pusat rehabilitas lebih banyak wisatawan yang datang ke Bukit Lawang dan Bukit Lawang menjadi salah satu tujuan paling populer di Sumatera.

\subsubsection{Pariwisata}

Menurut Kodhyat (2013), menyatakan bahwa kepariwisataan adalah suatu fenomena yang ditimbulkan oleh salah satu bentuk kegiatan manusia, yaitu kegiatan yang dalam bahasa Inggris disebut "travel"dan dalam bahasa Indonesia "perjalanan" dan/atau "wisata". Secara etimologis, kata "wisata" berasal dari bahasa Sansekerta yang dalam bahasa Indonesia berarti "perjalanan" atau "travel" dalam bahasa Inggris. Kata perjalanan mempunyai arti yang bersifat lebih umum, yaitu pergi kesuatu tempat, sedangkan kata wisata mengandung konotasi tertentu. Menurut Sihite dalam (Marpaung dan Bahar,2000) menjelaskan definisi pariwisata sebagai berikut: pariwisata adalah suatu perjalanan yang dilakukan orang untuk sementara waktu, yang diselenggarakan dari suatu tempat ke tempat lain meninggalkan tempatnya semula, dengan suatu perencanaan dan dengan maksud bukan untuk berusaha atau mencari nafkah di tempat yang dikunjungi, tetapi semata-mata untuk menikmati kegiatan pertamasyaan dan rekreasi atau untuk memenuhi keinginan yang beraneka ragam.

$$
\text { Menurut Soekadijo (2000) }
$$

mendefenisikan pariwisata sebagai segala kegiatan dalam masyarakat yang berhubungan dengan wisatawan. Pariwisata memberikan peluang kepada masyarakat untuk berusaha dan berwirausaha, jenis-jenis usaha yang ada kaitannya dengan pariwisata tergantung dari kreatifitas para pengusaha swasta baik yang bermodal kecil maupun besar untuk 
memberikan jasa atau menawarkan produk yang sekiranya diperlukan oleh wistawan. Industri pariwisata adalah keseluruhan usahausaha yang dapat dinikmati wisatawan semenjak awal mula proses ketertarikan untuk berwisata, menikmati lokasi daerah tujuan wisata sampai pada proses akhir wisatawan tersebut pulang menginjakkan kakinya sampai dirumah, kemudian mengenangnya.

\subsubsection{Wisatawan}

Menurut Suryadana (2013) wisatawan adalah orang yang melakukan perjalanan untuk berlibur, berobat, berbisnis, berolahraga, serta menuntut ilmu dan mengunjungi tempattempat yang indah atau sebuah Negara tertentu. Kata wisatawan (Tourist) merujuk kepada "orang", dalam pandangan umum, wisatawan menjadi bagian dari "Traveller" atau seorang "Visitor", seorang "Visitor" adalah seorang "Traveller" akan tetapi tidak semua Traveller adalah Tourist, Traveller memiliki sebuah konsep yang lebih luas, yang dapat mengacu kepada orang yang mempunyai beragam peran dalam masyarakat yang melakukan kegiatan rutin ketempat kerja, sekolah dan sebagai aktivitas sehari-hari, orang-orang dalam kategori ini, sama sekali tidak dapat dikatakan sebagai Tourist.

\subsubsection{Motivasi Wisatawan}

Menurut Sadirman (2001) kata "motif" diartikan sebagai daya upaya yang mendorong seseorang untuk melakukan sesuatu. Motif dapat dikatakan sebagai daya penggerak dari dalam dan didalam subjek untuk melakukan aktivitas-aktivitas tertentu demi mencapai satu tujuan. Berawal dari kata "motif" itu, maka motivasi dapat diartikan sebagai daya penggerak yang telah aktif. Motif menjadi aktif pada saat-saat tertentu, terutama bila kebutuhan untuk mencapai tujuan sangat dirasakan/mendesak.

Menurut Fahmi (2013) motivasi adalah aktivitas perilaku yang bekerja dalam usaha memenuhi kebutuhan-kebutuhan yang diinginkan. Menurut I Gde Pitana (2005) motivasi wisatawan merupakan hal yang sangat mendasar dalam studi tentang wisatawan dan pariwisata, karena motivasi merupakan trigger dari proses perjalanan wisata, walau motivasi ini acapkali tidak disadari secara penuh oleh wisatawan itu sendiri. Menurut Maslow dan Stanford dalam Utama (2011) menerangkan bahwa motivasi yang menggerakkan para wisatawan untuk mencapai tujuannya untuk membangkitkan dorongan dalam diri. Tingkah laku seseorang dipengaruhi oleh keinginan, kebutuhan, tujuan dan kepuasannya, baik yang berasal dari diri sendiri (internal dan dari luar lingkungannya eksternal).

\subsection{Tinjauan Umum Tentang Atraksi Wisata.}

Menurut Yoeti (2002) atraksi wisata adalah segala sesuatu yang menjadi daya tarik bagi orang untuk mengunjungi suatu daerah tertentu. Ada 3 syarat dalam pengembangan suatu daerah tujuan wisata agar menarik untuk dikunjungi oleh wisatawan potensial dalam berbagai pasar, yaitu

1. "Something to see". Artinya ditempat tersebut harus ada objek wisata dan atraksi wisata yang berbeda dengan apa yang dimiliki oleh daerah lain.

2. "Something to do". Artinya di tempat tersebut setiap banyak yang dapat dilihat dan disaksikan, harus pula disediakan fasilitas rekreasi yang dapat membuat wisatawan betah tinggal lebih lama di tempat itu.

3. "Something to buy". Artinya di tempat tersebut harus tersedia fasilitas untuk berbelanja (shopping), terutama barangbarang Souvenir dan kerajinan rakyat sebagai oleh-oleh untuk dibawa pulang ke tempat asal wisatawan.

Menurut Soekadijo

mengemukakan bahwa syarat-syarat yang harus dipenuhi perihal atraksi wisata yang baik: (1) Kegiatan (act) dan objek (artifact) yang merupakan atraksi itu sendiri harus dalam keadaan baik; (2) Karena atraksi wisata itu harus disajikan dihadapan wisatawan, maka citra penyajiannya (presentasinya) harus tepat; (3) Atraksi wisata adalah terminal dari suatu mobilitas spasial, yaitu akomodasi, transportasi, dan promosi serta pemasaran; (4) Keadaan di tempat atraksi harus dapat menahan wisatawan cukup lama; dan (5) Kesan yang diperoleh wisatawan waktu menyaksikan atraksi wisata harus diusahakan supaya bertahan selama mungkin.

Menurut Kuncoro dalam Nandi (2008) bahwa atraksi wisata dikelompokkan menjadi dua yaitu: (1) Atraksi sumber daya alam adalah setiap ekosistem dan segala isinya. Sumber daya alam fisik dan hayati merupakan atraksi wisata yang dapat di kembangkan untuk objek wisata alam; dan (2) Atraksi buatan manusia meliputi atraksi budaya (agama, budaya modern, museum, galeri, seni, situs arkeologi, bangunan), tradisi (kepercayaan, animism budaya, festival) dan peristiwa olahraga (olimpiade, piala dunia, turnamen). Menurut Marpaung (2000) atraksi wisata adalah suatu bentukan dari aktivitas 
dan fasilitas yang berhubungan, yang dapat menarik minat wisatawan atau pengunjung untuk datang ke suatu daerah atau tempat tertentu. Menurut Nuriata (2014) atraksi wisata dapat diartikan sebagai sesuatu yang berwujud atau tidak berwujud yang dapat memikat seseorang sehingga mengadakan perjalanan untuk dapat mencapainya serta dapat memberikan kepuasan kepada orang tersebut atas kegiatan yang dilakukan ditempat atraksi wisata tersebut. Atraksi wisata sebaiknya dapat mempertahankan keutuhan yang kekal (sustainable)agar dapat dimanfaatkan sebagai elemen produk paket wisata.

Pilihan atraksi wisata ditentukan oleh: (1) Profil wisatawan; (2)Tingkat pendidikan wisatawan; (3) Motivasi wisatawan; dan (4) Tipologi wisatawan. Suatu atraksi dapat diwujudkan menjadi atraksi wisata bila atraksi tersebut dapat memenuhi hal-hal sebagai berikut: (1) Keunikan, hal yang bersifat eksotik dari atraksi wisata; (2) Memenuhi selera wisatawan; (3) Bersifat santai dilakukan tidak tergesa-gesa, dinikmati dengan baik; (4) Mengundang unsur pendidikan/edukasi; (5) Mempunyai daya dukung lahan yang memadai; dan (6) Aksesibilitas, kemudahan mencapai tempat atraksi wisata.

Menurut Chaplin (2008) mendefenisikan atraksi wisata adalah sesuatu yang mempunyai beberapa kualitas yang mampu mendatangkan tingkah laku yang menyebabkan adient behavior yaitu kecenderungan untuk mendekati sumber. Atraksi wisata adalah daya tarik dari suatu objek pariwisata ataupun hasil kesenian suatu daerah tertentu yang dapat menarik wisatawan/turis asing untuk berkunjung menuju ketempat wisata tersebut. Menurut Ismayanti (2005) atraksi wisata adalah fokus utama penggerak pariwisata disebuah destinasi.Dalam arti, daya tarik wisata sebagai penggerak utama yang memotivasi wisatawan untuk mengunjungi suatu tempat

\subsubsection{Faktor- faktor motivasi wisatawan.}

Terdapat beberapa faktor yang dapat mempengaruhi/menarik keputusan seseorang untuk melakukan perjalanan. Fakor penarik ini sesungguhnya merupakan faktor internal dan eksternal yang memotivasi wisatawan untuk mengambil keputusan untuk melakukan perjalanan. Faktor pendorong umumnya bersifat social-psikologis, atau merupakan personal specific motivation, sedangkan faktor penarik merupakan destination specific attributes (Pitana,2005).

Pentingnya push and pull factors ini didalam pariwisata dijelaskan oleh Rhicardson dalam (Pitana,2005): (1) Push factors are all the economic, social demographic, technological and political forces that stimulate a demand for tourism activity by "pushing" consumers away from their usual place of residence. These are the dominant factors when people decide they want to get away from it all, but are vegue about where they want to go; (2) Pull factors are those which "pull" consumers towards a particular destination (e.g. a positive image, safety, attractions, climate). Forms of tourism are among pull factors-the destination's offering to tourists

Menurut Dann dalam (Pitana, 2005) mengemukakan bahwa faktor pendorong utama seseorang untuk melakukan perjalanan wisata (khususnya dari Negara Barat ke Dunia Ketiga) adalah untuk melepaskan diri dari tekanan psikis dalam kehidupan sehari-hari di Negara industri. Dengan adanya faktor pendorong, maka seseorang ingin melakukan perjalanan wisata, tetapi belum jelas daerah mana yang akan dituju. Ryan dalam (Pitana, 2005) menemukan berbagai fakor pendorong bagi seseorang untuk melakukan perjalanan wisata seperti dibawah ini: (1) Escape, Ingin melepaskan diri dari lingkungan yang dirasakan menjemukan, atau kejenuhan dari pekerjaan sehari-hari; (2) Relaxation, keinginan untuk rekuperasi/penyegaran, yang juga berhubungan dengan motivasi untuk Escape diatas; (3) Play, ingin menikmati kegembiraan, melalui berbagai permainan, yang merupakan pemunculan kembali dari sifat kekanak-kanakan, dan melepaskan diri sejenak dari berbagai urusan yang serius; (4) Strengthening family bonds, ingin mempererat hubungan kekerabatan, khususnya dalam konteks VFR (Visiting Friends and Relations). Keakraban hubungan kekerabatan ini juga terjadi diantara anggota keluarga yang melakukan perjalanan bersama-sama, karena kebersamaan sangat sulit diperoleh dalam suasana kerja sehari-hari di Negara industri; (5) Prestige, untuk menunjukkan gengsi, dengan mengunjungi destinasi yang menunjukkan kelas dan gaya hidup, yang juga merupakan dorongan untuk meningkatkan status atau derajat social. Bagi berbagai masyarakat, perjalanan keluar merupakan salah satu bentuk inisiasi; (6) Social interaction. Untuk dapat melakukan interaksi social dengan teman sejawat, atau dengan masyarakat lokal yang dikunjungi; (7) Romance, keinginan untuk bertemu dengan orang-orang yang bisa memberikan suasana romantic, atau untuk memenuhi kebutuhan 
seksual, khususnya dalam pariwisata seks; (8) Educational opportunity, keinginan untuk melihat sesuatu yang baru, mempelajari orang lain dan/atau daerah lain, atau mengetahui kebudayaan etnis lain. Ini merupakan pendorong dominan didalam pariwisata Indonesia; (9) Self-fulfilment, keinginan untuk menemukan diri sendiri (Self discovery), karena diri sendiri biasanya bisa ditemukan pada saat kita menemukan daerah atau orang yang baru; dan (10) Wish-fulfilment, keinginan untuk merealisasikan mimpi-mimpi yang lama dicita-citakan, sampai mengorbankan diri dengan cara berhemat, agar bisa melakukan perjalanan. Hal ini juga sangat jelas dalam perjalanan wisata religious, sebagai bagian dari keinginan atau dorongan yang kuat dari dalam diri.

Sedangkan menurut Jackson dalam (Pitana,2005) juga telah mengidentifikasi berbagai faktor penarik dan pendorong, menurutnya ada delapan faktor pendorong yang dapat di identifikasi yaitu: ego enhancement, itual inversion, pilgrimage, religion, health, education, perceived, authencity, dan conventions/conferences, sementara dari sisi penarik yaitu: location climate, national promotion, retail advertising, wholesale marketing, special events, incentive schemes, visting friends, visiting relatives, tourist atractions, culture, dan natural environment man-made environment. Pada umumnya tujuan utama wisatawan untuk berwisata adalah mendapat kesenangan.Namun wisatawan modern pada akhir-akhir ini selama perjalanan berwisata ingin meraih beberapa manfaat. Ada 2 (dua) faktor penting yang menentukan kepergian kemacetan untuk berwisata yaitu: (Suryadana,2013)

1. Faktor Pendorong

Faktor yang mendorong seseorang untuk berwisata adalah ingin terlepas (meskipun hanya ingin sejenak) dari kehidupan yang routine setiap hari, lingkungan yang tercemar, kecepatan lalu lintas dan hiruk pikuk kesibukan di kota.

2. Faktor Penarik

Faktor ini berkaitan dengan adanya atraksi wisata di daerah atau di tempat tujuan wisata. Atraksi wisata ini dapat berupa kemashuran akan objek, tempat-tempat yang banyak diperbincangkan orang, serta sedang menjadi berita. Dorongan berkunjung ke tempat teman atau keluarga atau ingin menyaksikan kesenian serta pertandingan olah raga yang sedang berlangsung juga menjadi daya tarik di daerah tujuan wisata.

\subsubsection{Kepuasan Wisatawan}

Menurut Kotler dalamUtama (2011) Kepuasan konsumen merupakan salah satu tujuan penting bagi aktivitas bisnis. Kepuasan konsumen juga dipandang sebagai salah satu indikator terbaik untuk meraih laba dimasa yang akan datang. Fakta yang menunjukkan bahwa menarik konsumen baru lebih mahal daripada mempertahankan konsumen yang ada, juga menjadi pemicu mingkatnya upaya untuk menjaga kepuasan konsumen.Kepuasan merupakan salah satu indikator yang memengaruhi loyalitas. Semakin tinggi tingkat kepuasan, maka loyalitas akan semakin tinggi.

Zeithaml dan Oliver dalam Utama (2011) menyatakan bahwa kepuasan merupakan pemenuhan respons konsumen, kepuasan konsumen juga merupakan evaluasi terhadap surprise yang melekat pada pemerolehan produk dan atau pengalaman. Dengan kata lain kepuasan konsumen merupakan penilaian evaluatif konsumen setelah melakukan pembelian atau purnabeli yang dihasilkan dari seleksi pembelian spesifik. Menurut Tjiptono dalam Utama(2011) metode yang digunakan untuk mengukur kepuasan konsumen dapat dengan cara: (1) Pengukuran dapat dilakukan secara langsung dengan pertanyaan; (2) Responden diberi pertanyaan seberapa mereka mengharapkan suatu atribut tertentu dan seberapa besar yang dirasakan; (3) Responden diminta untuk menuliskan masalah yng mereka hadapi berkaitan dengan penawaran dari perusahaan dan juga diminta untuk menuliskan masalah-masalah yang mereka hadapi berkaitan dengan penawaran dari perusahaan dan juga diminta untuk menuliskan perbaikan yang mereka sarankan; dan (4) Responden dapat diminta untuk memberi penilaian berbagai elemen dari penawaran berdasarkan derajat pentingnya, setiap elemen, dan seberapa baik kinerja perusahaan dalam masing-masing elemen.

Menurut Tze dan Wang dalam Utama (2011) kepuasan wisatawan terhadap destinasi pariwisata adalah konsep yang multi dimensi yang terdiri dari banyak faktor yang salit terkait. Salah satu faktor yang membuat wisatawan puas, mungkin faktor lainnya tidak mampu memuaskan wisatawan.A spek destinasi yang terdiri dari atraksi, amenitas, dan aksesibilitasnya mungkin memiliki kesamaan antara destinasi namun, untuk aspek ensilari dalam hal ini jasa yang bersifat tak berwujud sangat dinamis dan cenderung 
menuntut kualitas yang semakin meningkat dari waktu ke waktu.

Menurut Zeithaml dan Bitner dalam Susatyo (2014) mengemukakan bahwa kepuasan konsumen adalah penilaian konsumen atas produk ataupun jasa dalam hal menilai apakah produk atau jasa tersebut telah memenuhi kebutuhan dan ekspektasi pelanggan. Terdapat 3 metode yang bisa dipakai untuk mengukur tinggi tidaknya kepuasan pelanggan terhadap suatu perusahaan menurut Koter dan Keller dalam (Susatyo,2014) yaitu: (1) Periodic Surveys (survey berkala); (2) Customer loss rate (tingkat kehilangan pelanggan); dan (3) Mystery shoppers (pelanggan misterius).

Menurut Wikie dalam Utama (2011) menyatakan bahwa terdapat 5 elemen dalam kepuasan konsumen, yaitu:

1. Expectations. Harapan konsumen terhadap suatu barang atau jasa telah dibentuk sebelum konsumen membeli barang atau jasa tersebut. Pada saat proses pembelisn dilakukan, konsumen berharap bahwa barang atau jasa yang mereka, konsumen berharap bahwa barang atau jasa yang mereka terima sesuai dengan harapan, keinginan dan keyakinan mereka. Barang atau jasa yang sesuai dengan harapan konsumen akan menyebabkan konsumen merasa puas

2. Performance. Pengalaman konsumen terhadap kinerja aktual barang atau jasa ketika digunakan tanpa dipengaruhi oleh harapan mereka. Ketika kinerja aktual barang atau jasa berhasil maka konsumen akan merasa puas

3. Comparison. Hal ini dilakukan dengan membandingkan hrapan kinerja barang atau jasa sebelum membeli dengan persepsi kinerja aktual barang atau jasa tersebut. Konsumen akan merasa puas ketika harapan sebelum pembelian sesuai atau melebihi persepsi mereka terhadap kinerja aktual produk

4. Confirmation/disconfirmation. Harapan konsumen dipengaruhi oleh pengalaman mereka terhadap penggunaan merek dari barang atau jasa yang berbeda dari orang lain. Confirmation terjadi bila harapn sesuai dengan kinerja aktual produk. Sebaliknya disconfirmation terjadi ketika harapan lebih tinggi atau lebih rendah dari kinerja aktual produk. Konsumen akan merasa puas ketika terjadi confirmation/disconfirmation

\subsection{Metode Penelitian dan Teknik Pengumpulan Data}

Metode penelitian yang digunakan penulis adalah metode deskriptif, merupakan suatu model dalam meneliti status sekelompok manusia, suatu objek, suatu set kondisi, suatu sistem pemikiran ataupun suatu kelas peristiwa pada masa sekarang. Sugiyono (2010) menyatakan bahwatdeskriptif adalah suatu metode yang digunakan untuk menggambarkan atau menganalisis suatu hasil penelitian tetapi tidak digunakan untuk menggambarkan atau menganalisis suatu hasil penelitian tetapi tidak digunakan untuk menggambarkan kesimpulan yang lebih luas.

Teknik pengumpulan data yang digunakan adalah: (1) Observasi, dengan terjun langsung ke lokasi penelitian untuk mencari data yang dibutuhkan dalam penelitian; (2) Studi kepustakaan, dengan pengumpulan data yang dilakukan dengan cara mengumpulkan bukubuku, ataupun diktat sebagai bahan referensi, serta sumber lainnya yang berkaitan dengan masalah yang diteliti; dan (3) Kuesioner, dengan menyediakan daftar pertanyaan tertulis yang dibuat penulis dan disebarkan kepada wisatawan yang berkunjung ke Bukit Lawang guna mendapatkan jawaban-jawaban yang diperlukan sehubungan dengan masalahmasalah yang diangkat dan objek yang diteliti.

\subsubsection{Populasi dan Sample}

Menurut Sugiyono (2010) populasi adalah keseluruhan subjek dan objek penelitian yang sebagai sumber data yang memiliki karateristik tertentu yang ditetapkan oleh peneliti untuk dipelajari dan kemudian ditarik kesimpulannya. Oleh karena itu yang dimaksud populasi dalam penelitian adalah wisatawan yang melakukan kegiatan trekking di Bukit Lawang, Kecamatan Bahorok. Adapun teknik pengambilan sampel tersebut dilakukan dengan cara Accident Sampling, yaitu teknik penentuan sampel berdasarkan kebetulan yaitu, siapa saja yang secara kebetulan bertemu dan dipandang orang tersebut cocok dan dapat dijadikan sebagai sumber data. Jumlah sampel tersebut sebanyak 50 orang responden. Menurut Arikunto (2006) apabila jumlah populasi kurang dari 100 orang sebaiknya diambil semua sedangkan apabila jumlahnya cukup besar dapat diambil 10\%$15 \%$ atau $25 \%-35 \%$. Dengan demikian secara teoritis sampel yang berjumlah sebanyak 50 orang sudah memenuhi ketentuan.

\subsubsection{Instrumen Penelitian}

Instrument penelitian ini menggunakan kuisioner skala likert. Adapun atribut-atribut tersebut sudah peneliti uraikan pada bagian variable data. Untuk memudahkan penilaian 
dari jawaban responden maka, dalam penelitian ini :

Tabel 1. Kriteria Pengukuran Skor Jawaban Responden.

\begin{tabular}{|c|c|}
\hline Jawaban Responden & Skor \\
\hline Sangat Setuju (SS) & 5 \\
\hline Setuju (S) & 4 \\
\hline Ragu (R) & 3 \\
\hline Tidak Setuju (TS) & 2 \\
\hline Sangat Tidak Setuju (STS) & 1 \\
\hline
\end{tabular}

Sumber: (Sugiyono, 2010)

\subsection{Hasil Penelitian}

Analisis dilakukan berdasarkan kuesioner yang telah disebarkan oleh penulis, dan diisi oleh wisatawan yang datang ke objek wisata Bukit Lawang. Suatu objek wisata dapat dikatakan layak menjadi suatu daerah tujuan wisata apabila memiliki suatu atraksi, tentu saja atraksi yang dimaksud adalah segala sesuatu yang dapat dilihat, dilakukan, kemudian dapat dibeli. Ketika hal tersebut adalah merupakan hal yang menjadi daya tarik suatu objek wisata, daya tarik dari suatu objek pariwisata ataupun hasil kesenian suatu daerah tertentu yang dapat menarik wisatawan/turis asing untuk berkunjung menuju ketempat wisata tersebut

Tabel 2. Tanggapan Wisatawan Trekking di

Bukit Lawang Lebih Unik Dibandingkan Daerah lain, $n=50$

\begin{tabular}{|c|c|c|c|}
\hline $\begin{array}{c}\mathbf{N} \\
\mathbf{0}\end{array}$ & $\begin{array}{c}\text { Jawaban } \\
\text { responden }\end{array}$ & $\begin{array}{c}\text { Jumlah } \\
\text { (orang) }\end{array}$ & $\begin{array}{c}\text { Perse } \\
\text { ntase }\end{array}$ \\
\hline 1 & Sangat Setuju & 3 & $6 \%$ \\
\hline 2 & Setuju & 7 & $14 \%$ \\
\hline 3 & Tidak Setuju & 25 & $50 \%$ \\
\hline 4 & Sangat Tidak Setuju & 15 & $30 \%$ \\
\hline \multicolumn{2}{|c|}{ Total } & 50 & $100 \%$ \\
\hline
\end{tabular}

Sumber : Hasil olahan kuesioner, 2018

Dari tabel diatas dapat diketahui bahwa wisatawan yaitu 3 orang responden dengan persentase $6 \%$ mengatakan sangat setuju bahwa trekking di Bukit Lawang lebih unik daibandingkan dengan trekking lainnya, sedangkan 7 orang responden dengan 14\% persentase mengatakan setuju bahwa trekking Bukit Lawang unik dibandingkan dengan trekkingdi daerah lainnya. Sementara 25 orang responden dengan $50 \%$ persentase mengatakan tidak setuju bahwa trekkingdi Bukit Lawang lebih unik dibandingkan di daerah lainnya, dan sisanya yaitu 15 orang responden dengan $30 \%$ persentase mengatakan sangat tidak setuju bahwa trekkingdi Bukit Lawang lebih unik dibandingkan daerah lainnya.

Tabel 3. Tanggapan Wisatawa atas Kegiatan Trekking Memenuhi Keinginan Wisatawan, $n=50$

\begin{tabular}{|c|c|c|c|}
\hline No & $\begin{array}{c}\text { Jawaban } \\
\text { responden }\end{array}$ & $\begin{array}{c}\text { Jumlah } \\
\text { (orang) }\end{array}$ & Persentase \\
\hline
\end{tabular}

\begin{tabular}{|c|c|c|c|}
\hline 1 & Sangat Setuju & 8 & $16 \%$ \\
\hline 2 & Setuju & 5 & $10 \%$ \\
\hline 3 & Tidak Setuju & 20 & $40 \%$ \\
\hline 4 & Sangat Tidak Setuju & 17 & $34 \%$ \\
\hline \multicolumn{2}{|c|}{ Total } & 50 & $100 \%$ \\
\hline
\end{tabular}

Sumber : Hasil olahan kuesioner, 2018

Berdasarkan tabel diatas dapat dianalisis bahwa sebagian besar wisatawan yaitu 8 orang responden dengan persentase $16 \%$ menyatakan sangat setuju bahwa trekking di Bukit Lawang sudah memenuhi keinginan wisatawan, sedangkan 5 orang responden dengan presentase $10 \%$ menyatakan setuju bahwa trekking di Bukit Lawang sudah memenuhi keinginan wisatawan, sementara 20 orang responden dengan presentase $40 \%$ menyatakan tidak setuju bahwa trekking di Bukit Lawang sudah memenuhi keinginan wisatawan, dan sisanya 17 orang responden dengan presentase $34 \%$ menyatakan sangat tidak setuju bahwa trekking di Bukit Lawang sudah memenuhi keinginan wisatawan

Tabel 4. Tanggapan Wisatawan Terhadap

Trekking Bersifat Santai dan Wisatawan

Menikmati Aktivitas Trekking, $\mathrm{n}=\mathbf{5 0}$

\begin{tabular}{|c|c|c|c|}
\hline No & Jawaban responden & $\begin{array}{c}\text { Jumlah } \\
\text { (orang) }\end{array}$ & Persentase \\
\hline 1 & Sangat Setuju & 4 & $8 \%$ \\
\hline 2 & Setuju & 5 & $10 \%$ \\
\hline 3 & Tidak Setuju & 22 & $44 \%$ \\
\hline 4 & Sangat Tidak Setuju & 19 & $38 \%$ \\
\hline \multicolumn{2}{|c|}{ Total } & 50 & $100 \%$ \\
\hline
\end{tabular}

Sumber : Hasil olahan kuesioner, 2018

Berdasarkan tabel diatas dapat dianalisis bahwa sebagian besar wisatawan yaitu 4 orang responden dengan persentase 8\% menyatakan sangat setuju bahwa trekking di Bukit Lawang bersifat santai dan pengunjung menikmati aktivitas trekking, sedangkan 5 orang responden dengan persentase $10 \%$ menyatakan tidak setuju bahwa trekking di Bukit lawang bersifat santai dan pengunjung menikmatinya, sementara 22 orang responden dengan persentase 44\% tidak setuju bahwa trekking di Bukit Lawang bersifat santai dan pengunjung menikmatinya, namun 19 orang responden dengan persentase $38 \%$ menyatakan sangat tidak setuju bahwa trekking di Bukit Lawang bersifat santai dan pengunjung menikmatinya.

Tabel 5. Tanggapan Wisatawan terhadap Trekking memiliki Unsur Pendidikan / Edukasi, $\mathrm{n}=\mathbf{5 0}$

\begin{tabular}{|c|c|c|c|}
\hline No & Jawaban responden & $\begin{array}{c}\text { Jumlah } \\
\text { (orang) }\end{array}$ & Persentase \\
\hline 1 & Sangat Setuju & 10 & $20 \%$ \\
\hline 2 & Setuju & 14 & $28 \%$ \\
\hline 3 & Tidak Setuju & 20 & $40 \%$ \\
\hline 4 & Sangat Tidak Setuju & 6 & $12 \%$ \\
\hline \multicolumn{2}{|c|}{ Total } & 50 & $100 \%$ \\
\hline
\end{tabular}

Sumber : Hasil olahan kuesioner, 2018 
Berdasarkan tabel diatas dapat dianalisis bahwa sebagian besar wisatawan yaitu 10 orang responden dengan persentase $20 \%$ menyatakan sangatsetuju bahwa trekking di Bukit Lawang memiliki unsur pendidikan dan edukasi, sedangkan 14 orang responden dengan persentase $28 \%$ menyatakan setuju bahwa trekking di Bukit Lawang memiliki unsur pendidikan dan edukasi, sementara 20 orang responden dengan persentase $40 \%$ menyatakan tidak setuju bahwa trekking di Bukit Lawang memiliki unsur pendidikan dan edukasi, namun 6 orang responden dengan persentase $12 \%$ menyatakan sangat tidak setuju bahwa trekking di Bukit Lawang memiliki unsur pendidikan dan edukasi

Tabel 6. Tanggapan Wisatawan Terhadap

Trekking di Bukit Lawang Memiliki Lahan Area

yang Layak dijadikan Berbagai Kegiatan

Pariwisata, $\mathbf{n}=50$

\begin{tabular}{|c|c|c|c|}
\hline No & Jawaban responden & $\begin{array}{c}\text { Jumlah } \\
\text { (orang) }\end{array}$ & Persentase \\
\hline 1 & Sangat Setuju & 8 & $16 \%$ \\
\hline 2 & Setuju & 19 & $38 \%$ \\
\hline 3 & Tidak Setuju & 15 & $30 \%$ \\
\hline 4 & Sangat Tidak Setuju & 8 & $16 \%$ \\
\hline \multicolumn{2}{|c|}{ Total } & 50 & $100 \%$ \\
\hline
\end{tabular}

Sumber : Hasil olahan kuesioner, 2018

Berdasarkan tabel diatas dapat dianalisis bahwa sebagian besar wisatawan yaitu 8 orang responden dengan persentase $16 \%$ menyatakan sangat setuju bahwa trekking Bukit Lawang memiliki lahan area yang layak dijadikan sebagai kegiatan pariwisata, sedangkan 19 orang responden dengan persentase 38\% menyatakan setuju bahwa trekking Bukit Lawang memiliki lahan area yang layak dijadikan sebagai kegiatan pariwisata, sementara 15 orang responden dengan persentase $30 \%$ menyatakan tidak setuju bahwa trekking Bukit Lawang memiliki lahan area yang layak dijadikan sebagai kegiatan pariwisata, namun 8 orang responden dengan $16 \%$ persentase menyatakan sangat tidak setuju bahwa trekking Bukit Lawang memiliki lahan area yang layak dijadikan sebagai kegiatan pariwisata.

\subsubsection{Analisis Terhadap Faktor Penarik - Pendorong Wisatawan dalam Berkunjung}

Faktor penarik merupakan faktor internal dan eksternal yang memotivasi wisatawan untuk mengambil keputusan untuk melakukan perjalanan. Faktor yang mendorong seseorang untuk berwisata adalah ingin terlepas (meskipun hanya ingin sejenak) dari kehidupan yang rutin setiap hari, lingkungan yang tercemar, kecepatan lalu lintas dan hiruk pikuk kesibukan di kota. Sedangkan faktor penarik adalah faktor yang berkaitan dengan adanya atraksi wisata di daerah atau di tempat tujuan wisata. Atraksi wisata ini dapat berupa kemashuran akan objek, tempat-tempat yang banyak diperbincangkan orang, serta sedang menjadi berita.

Tabel 7. Tanggapan Wisatawan Melaukan Trekking di Bukit Lawang dikarenakan Promosi Nasional, $\mathrm{n}=\mathbf{5 0}$

\begin{tabular}{|c|c|c|c|}
\hline No & Jawaban responden & $\begin{array}{c}\text { Jumlah } \\
\text { (orang) }\end{array}$ & Persentase \\
\hline 1 & Sangat Setuju & 2 & $4 \%$ \\
\hline 2 & Setuju & 5 & $10 \%$ \\
\hline 3 & Tidak Setuju & 24 & $48 \%$ \\
\hline 4 & Sangat Tidak Setuju & 19 & $38 \%$ \\
\hline \multicolumn{2}{|c|}{ Total } & 50 & $100 \%$ \\
\hline
\end{tabular}

Sumber : Hasil olahan kuesioner, 2018

Berdasarkan tabel diatas dapat dianalisis bahwa sebagian besar wisatawan yaitu 2 orang responden dengan persentase $4 \%$ menyatakan sangat setuju bahwa melakukan trekking Bukit Lawang karena mendapatkan promosi nasional, sedangkan 5 orang responden dengan persentase 10\% menyatakan setuju bahwa melakukan trekking Bukit Lawang karena mendapatkan promosi nasional, sementara 24 orang responden dengan persentase $48 \%$ menyatakan bahwa melakukan trekking Bukit Lawang karena mendapatkan promosi nasional, namun 19 orang responden dengan persentase 38\% menyatakan sangat tidak setuju bahwa melakukan trekking Bukit Lawang karena mendapatkan promosi nasional.

Tabel 8. Tanggapan Kondisi Alam Bukit Lawang Sangat Baik, $n=50$

\begin{tabular}{|c|c|c|c|}
\hline No & Jawaban responden & $\begin{array}{c}\text { Jumlah } \\
\text { (orang) }\end{array}$ & Persentase \\
\hline 1 & Sangat Setuju & 8 & $16 \%$ \\
\hline 2 & Setuju & 23 & $46 \%$ \\
\hline 3 & Tidak Setuju & 12 & $24 \%$ \\
\hline 4 & Sangat Tidak Setuju & 7 & $14 \%$ \\
\hline \multicolumn{2}{|c|}{ Total } & 50 & $100 \%$ \\
\hline
\end{tabular}

Sumber : Hasil olahan kuesioner, 2018

Berdasarkan tabel diatas dapat dianalisis bahwa sebagian besar wisatawan yaitu 8 orang responden dengan persentase $16 \%$ menyatakan sangat setuju bahwa kondisi alam di Bukit Lawang sangat baik, sedangkan23 orang responden dengan persentase $46 \%$ menyatakan setuju bahwa kondisi alam di Bukit Lawang sangat baik, sementara 12 orang resonden dengan $24 \%$ menyatakan tidak setuju bahwa kondisi alam di Bukit Lawang sangat baik, namun 7 orang responden dengan persentase $14 \%$ menyatakan bahwa kondisi alam di Bukit Lawang sangat baik.

Tabel 9. Tanggapan Wisatawan Melakukan Trekking

Untuk Menikmati Atraksi Wisata Yang Ada, $\mathbf{n}=50$

\begin{tabular}{|c|c|c|c|}
\hline No & $\begin{array}{c}\text { Jawaban } \\
\text { responden }\end{array}$ & $\begin{array}{c}\text { Jumlah } \\
\text { (orang) }\end{array}$ & Persentase \\
\hline
\end{tabular}




\begin{tabular}{|c|c|c|c|}
\hline 1 & Sangat Setuju & 8 & $16 \%$ \\
\hline 2 & Setuju & 20 & $40 \%$ \\
\hline 3 & Tidak Setuju & 12 & $24 \%$ \\
\hline 4 & Sangat Tidak Setuju & 10 & $20 \%$ \\
\hline \multicolumn{2}{|c|}{ Total } & 50 & $100 \%$ \\
\hline
\end{tabular}

Sumber : Hasil olahan kuesioner, 2018

Berdasarkan tabel diatas dapat dianalisis bahwa sebagian besar wisatawan yaitu 8 orang responden dengan persentase $16 \%$ menyatakan sangat setuju bahwa melakukan trekking di Bukit Lawang untuk menikmati atraksi wisata yang ada, sedangkan 20 orang responden dengan persentase $40 \%$ menyatakan setuju bahwa melakukan trekking di Bukit Lawang untuk menikmati atraksi wisata yang ada, sementara 12 orang responden dengan 24\% menyatakan tidak setuju bahwa melakukan trekking di Bukit Lawang untuk menikmati atraksi wisata yang ada, namun 10 orang responden dengan persentase $20 \%$ menyatakan sangat tidak setuju bahwa melakukan trekking di Bukit Lawang untuk menikmati atraksi wisata yang ada.

Tabel 10. Tanggapan Wisatawan melakukan Treeking untuk Acara Khusus, $\mathrm{n}=\mathbf{5 0}$

\begin{tabular}{|c|c|c|c|}
\hline No & Jawaban responden & $\begin{array}{l}\text { Jumlah } \\
\text { (orang) }\end{array}$ & Persentase \\
\hline 1 & Sangat Setuju & 2 & $4 \%$ \\
\hline 2 & Setuju & 7 & $14 \%$ \\
\hline 3 & Tidak Setuju & 19 & $38 \%$ \\
\hline 4 & Sangat Tidak Setuju & 22 & $44 \%$ \\
\hline \multicolumn{2}{|r|}{ Total } & 50 & $100 \%$ \\
\hline
\end{tabular}

Sumber : Hasil olahan kuesioner, 2018

Berdasarkan tabel diatas dapat dianalisis bahwa sebagian besar wisatawan yaitu 2 orang responden dengan persentase $4 \%$ menyatakan sangat setuju bahwa melakukan trekking di Bukit Lawang untuk acara khusus, sedangkan 7 orang responden dengan 14\% menyatakan setuju bahwa melakukan trekking di Bukit Lawang untuk acara khusus, sementara 19 orang responden dengan persentase $38 \%$ menyatakan tidak setuju bahwa melakukan trekking di Bukit Lawang untuk acara khusus, namun 22 orang responden dengan persentase $44 \%$ menyatakan sangat tidak setuju bahwa melakukan trekking di Bukit Lawang untuk acara khusus,

Tabel 11. Tanggapan Wisatawan Melakukan

Trekking Bertujuan Untuk Berteu Teman, Kerabat, dan Keluarga, $\mathbf{n}=\mathbf{5 0}$

\begin{tabular}{|c|c|c|c|}
\hline & & \\
\hline No & Jawaban responden & $\begin{array}{l}\text { Jumlah } \\
\text { (orang) }\end{array}$ & Persentase \\
\hline 1 & Sangat Setuju & 1 & $2 \%$ \\
\hline 2 & Setuju & 5 & $10 \%$ \\
\hline 3 & Tidak Setuju & 30 & $60 \%$ \\
\hline 4 & Sangat Tidak Setuju & 14 & $28 \%$ \\
\hline & Total & 50 & $100 \%$ \\
\hline
\end{tabular}

Sumber : Hasil olahan kuesioner, 2018
Berdasarkan tabel diatas dapat dianalisis bahwa sebagian besar wisatawan yaitu 1 orang responden dengan persentase $2 \%$ menyatakan sangat setuju bahwa melakukan trekking di Bukit Lawang untuk tujuan bertemu teman, kerabat, dan keluarga, sedangkan 5 orang responden dengan persentase $10 \%$ menyatakan setuju bahwa melakukan trekking di Bukit Lawang untuk tujuan bertemu teman, kerabat, dan keluarga, sementara 30 orang responden dengan persentase $60 \%$ menyatakan tidak setuju bahwa melakukan trekking di Bukit Lawang untuk tujuan bertemu teman, kerabat, dan keluarga, namun 14 orang responden dengan persentase $28 \%$ menyatakan bahwa melakukan trekking di Bukit Lawang untuk tujuan bertemu teman, kerabat, dan keluarga,

Tabel 12. Tanggapan Wisatawan Dalam

Melakkukan Trekking Untuk Melepaskan Diri Dari Pekerjaan Sehari-hari, $\mathbf{n}=\mathbf{5 0}$

\begin{tabular}{|c|c|c|c|}
\hline No & Jawaban responden & $\begin{array}{c}\text { Jumlah } \\
\text { (orang) }\end{array}$ & Persentase \\
\hline 1 & Sangat Setuju & 3 & $6 \%$ \\
\hline 2 & Setuju & 7 & $14 \%$ \\
\hline 3 & Tidak Setuju & 25 & $50 \%$ \\
\hline 4 & Sangat Tidak Setuju & 15 & $30 \%$ \\
\hline \multicolumn{2}{|c|}{ Total } & 50 & $100 \%$ \\
\hline
\end{tabular}

Sumber : Hasil olahan kuesioner, 2018

Berdasarkan tabel diatas dapat dianalisis bahwa sebagian besar wisatawan yaitu 3 orang responden dengan persentase $6 \%$ menyatakan sangat setuju bahwa melakukan trekking di Bukit Lawanguntuk melepaskan diri dari pekerjaan sehari-hari, sedangkan 7 orang responden dengan persentase 14\% menyatakan setuju bahwa melakukan trekking di Bukit Lawang untuk melepaskan diri dari pekerjaan sehari-hari, sementara 25 orang responden dengan persentase $50 \%$ menyatakan tidak setuju bahwa melakukan trekking di Bukit Lawang untuk melepaskan diri dari pekerjaan seharihari, namun 15 orang responden dengan persentase $15 \%$ menyatakan bahwa melakukan trekking di Bukit Lawang untuk melepaskan diri dari pekerjaan sehari-hari

Dari hasil tersebut dapat diketahui bahwa wisatawan yang berkunjung dalam melakukan kegiatan trekking di Bukit Lawang bukan dengan tujuan melepaskan diri dari pekerjaan sehari-hari.Dapat dilihat bahwa pengambilan keputusan wisatawan bukan tergantung dari tujuan pribadi wisatawan namun terdapat sesuatu yang ingin dilihat dari suatu objek wisata tersebut.

Tabel 13. Tanggapan Wisatawan Melakukan

Trekking Untuk Menunjukkan Gengsi, $\mathbf{n}=\mathbf{5 0}$

\begin{tabular}{|l|l|l|l|}
\hline No & Jawaban responden & $\begin{array}{c}\text { Jumlah } \\
\text { (orang) }\end{array}$ & Persentase \\
\hline
\end{tabular}




\begin{tabular}{|c|c|c|c|}
\hline 1 & Sangat Setuju & 8 & $16 \%$ \\
\hline 2 & Setuju & 10 & $20 \%$ \\
\hline 3 & Tidak Setuju & 22 & $44 \%$ \\
\hline 4 & Sangat Tidak Setuju & 10 & $20 \%$ \\
\hline \multicolumn{2}{|c|}{ Total } & 50 & $100 \%$ \\
\hline
\end{tabular}

Sumber : Hasil olahan kuesioner, 2018

Berdasarkan tabel diatas dapat dianalisis bahwa sebagian besar wisatawan yaitu 8 orang responden dengan persentase $16 \%$ menyatakan sangat setuju bahwa melakukan trekking di Bukit Lawang untuk menunjukkan gengsi, sedangkan 10 orang responden dengan persentase $20 \%$ menyatakan setuju bahwa melakukan trekking di Bukit Lawang untuk menunjukkan gengsi, sementara 12 orang responden dengan 44\% menyatakan tidak setuju bahwa melakukan trekking di Bukit Lawang untuk menunjukkan gengsi, namun 10 orang responden dengan persentase $20 \%$ menyatakan sangat tidak setuju bahwa melakukan trekking di Bukit Lawang untukmenunjukkan gengsi.

Tabel 14. Tanggapan Wisatawan Melakukan Kegiatan Trekking Untuk Mendapatkan Pembelajaran, $\mathrm{n}=50$

\begin{tabular}{|c|c|c|c|}
\hline No & Jawaban responden & $\begin{array}{c}\text { Jumlah } \\
\text { (orang) }\end{array}$ & Persentase \\
\hline 1 & Sangat Setuju & 11 & $22 \%$ \\
\hline 2 & Setuju & 20 & $40 \%$ \\
\hline 3 & Tidak Setuju & 7 & $14 \%$ \\
\hline 4 & Sangat Tidak Setuju & 12 & $24 \%$ \\
\hline \multicolumn{2}{|c|}{ Total } & 50 & $100 \%$ \\
\hline
\end{tabular}

Sumber : Hasil olahan kuesioner, 2018

Berdasarkan tabel diatas dapat dianalisis bahwa sebagian besar wisatawan yaitu 11 orang responden dengan persentase $22 \%$ menyatakan sangat setuju bahwa melakukan trekking di Bukit Lawang untuk mendapatkan pembelajaran, sedangkan 20 orang responden dengan persentase $40 \%$ menyatakan setuju bahwa melakukan trekking di Bukit Lawang untuk mendapatkan pembelajaran, sementara 7 orang responden dengan 14\% menyatakan tidak setuju bahwa melakukan trekking di Bukit Lawang untuk mendapatkan pembelajaran, namun 12 orang responden dengan persentase $24 \%$ menyatakan sangat tidak setuju bahwa melakukan trekking di Bukit Lawang untuk mendapatkan pembelajaran.

Tabel 15. Tanggapan Wisatawan Melakukan Trekking Di Untuk Memenuhi Keinginan Diri, $\mathrm{n}=\mathbf{5 0}$

\begin{tabular}{|c|c|c|c|}
\hline No & Jawaban responden & $\begin{array}{c}\text { Jumlah } \\
\text { (orang) }\end{array}$ & Persentase \\
\hline 1 & Sangat Setuju & 9 & $18 \%$ \\
\hline 2 & Setuju & 18 & $36 \%$ \\
\hline 3 & Tidak Setuju & 20 & $40 \%$ \\
\hline 4 & Sangat Tidak Setuju & 3 & $6 \%$ \\
\hline \multicolumn{2}{|c|}{ Total } & 50 & $100 \%$ \\
\hline
\end{tabular}

Sumber : Hasil olahan kuesioner, 2018
Berdasarkan tabel diatas dapat dianalisis bahwa sebagian besar wisatawan yaitu 9 orang responden dengan persentase $18 \%$ menyatakan sangat setuju bahwa melakukan trekking di Bukit Lawang untuk memenuhi kebutuhan diri, sedangkan 18 orang responden dengan persentase $36 \%$ menyatakan setuju bahwa melakukan trekking di Bukit Lawang untuk memenuhi kebutuhan diri, sementara 20 orang responden dengan persentase $40 \%$, namun 3 orang responden dengan persentase $6 \%$

Tabel 16. Tanggapan Wisatawan Melakukan Trekking Untuk Mendapatkan Interaksi Sosial, $\mathbf{n}=\mathbf{5 0}$

\begin{tabular}{|c|c|c|c|}
\hline No & Jawaban responden & $\begin{array}{c}\text { Jumlah } \\
\text { (orang) }\end{array}$ & Persentase \\
\hline 1 & Sangat Setuju & 3 & $6 \%$ \\
\hline 2 & Setuju & 5 & $10 \%$ \\
\hline 3 & Tidak Setuju & 26 & $52 \%$ \\
\hline 4 & Sangat Tidak Setuju & 16 & $32 \%$ \\
\hline \multicolumn{2}{r|}{ Total } & 50 & $100 \%$ \\
\hline
\end{tabular}

Sumber : Hasil olahan kuesioner, 2018

Berdasarkan tabel diatas dapat dianalisis bahwa sebagian besar wisatawan yaitu 3 orang responden dengan persentase $6 \%$ menyatakan sangat setuju bahwa melakukan trekking di Bukit Lawang untuk mendapatkan interaksi sosial, sedangkan 5 orang responden dengan persentase $10 \%$ menyatakan setuju bahwa melakukan trekking di Bukit Lawang untuk mendapatkan interaksi sosial, sementara 26 orang responden dengan persentase $52 \%$ menyatakan tidak setuju bahwa melakukan trekking di Bukit Lawang untuk mendapatkan interaksi sosial, namun 16 orang responden dengan persentase $32 \%$ menyatakan bahwa melakukan trekking di Bukit Lawang untuk mendapatkan interaksi sosial

\subsubsection{Analisis Terhadap kepuasan wisatawan}

Kepuasan merupakan salah satu indikator yang mempengaruhi loyalitas. Semakin tinggi tingkat kepuasan, maka loyalitas akan semakin tinggi. Kepuasan merupakan pemenuhan respons konsumen, kepuasan konsumen juga merupakan evaluasi terhadap surprise yang melekat pada pemerolehan produk dan atau pengalaman.

Tabel 17. Tanggapan Wisatawan Terhadap

Kepuasan Akan Kondisi Objek Wisata Bukit Lawang, $\mathbf{n}=\mathbf{5 0}$

\begin{tabular}{|c|c|c|c|}
\hline No & $\begin{array}{c}\text { Jawaban } \\
\text { responden }\end{array}$ & $\begin{array}{c}\text { Jumlah } \\
\text { (orang) }\end{array}$ & Persentase \\
\hline 1 & Sangat Puas & 5 & $10 \%$ \\
\hline 2 & Puas & 12 & $24 \%$ \\
\hline 3 & Tidak Puas & 22 & $44 \%$ \\
\hline 4 & Sangat Tidak Puas & 11 & $22 \%$ \\
\hline \multicolumn{2}{|c|}{ Total } & 50 & $100 \%$ \\
\hline
\end{tabular}

Sumber : Hasil olahan kuesioner, 2018 
Berdasarkan tabel diatas dapat dianalisis bahwa sebagian besar wisatawan yaitu 5 orang responden dengan persentase $10 \%$ menyatakan sangat puas dengan kondisi objek wisata Bukit Lawang, sedangkan 12 orang responden dengan persentase $24 \%$ menyatakan puas dengan kondisi objek wisata Bukit Lawang, sementara 22 orang responden dengan persentase $44 \%$ menyatakan tidak puas dengam kondisi objek wisata di Bukit Lawang, selebihnya 11 orang responden dengan persentase $22 \%$ menyatakan sangat tidak puas dengan kondisi objek wisata Bukit Lawang

Tabel 18. Tanggapan Wisatawan Terhadap

Kepuasan Akan Ketersidaan Souvenir Yang Dijual Di Bukit Lawang, $\mathbf{n}=\mathbf{5 0}$

\begin{tabular}{|c|c|c|c|}
\hline No & $\begin{array}{c}\text { Jawaban } \\
\text { responden }\end{array}$ & $\begin{array}{c}\text { Jumlah } \\
\text { (orang) }\end{array}$ & Persentase \\
\hline 1 & Sangat Puas & 5 & $10 \%$ \\
\hline 2 & Puas & 12 & $24 \%$ \\
\hline 3 & Tidak Puas & 22 & $44 \%$ \\
\hline 4 & Sangat Tidak Puas & 11 & $22 \%$ \\
\hline \multicolumn{2}{|c|}{ Total } & 50 & $100 \%$ \\
\hline
\end{tabular}

Sumber : Hasil olahan kuesioner, 2018

Berdasarkan tabel diatas dapat dianalisis bahwa sebagian besar wisatawan yaitu 5 orang responden dengan persentase $10 \%$ menyatakan sangat puas akan ketersediaan souvenir yang dijual di Bukit Lawang, sedangkan 12 orang responden dengan persentase $24 \%$ menyatakan puas terhadap ketersediaan souvenir yang dijual di Bukit Lawang, sementara 22 orang responden dengan peresentase $44 \%$ menyatakan tidak puas terhadap ketersediaan souvenir yang dijual di Bukit Lawang, namun 11 orang responden dengan $22 \%$ menyatakan sangat tidak puas terhadap ketersediaan souvenir yang dijual di Bukit Lawang

Dari hasil tersebut dapat dianalisis bahwa ketersediaan souvenir di Bukit Lawang masih kurang, salah satu syarat sebagai daerah wisata adalah something to buy namun disana tidak terdapat beberapa penjual souvenir

Tabel 19. Tanggapan Wisatawan Terhadap Kepuasan Akan Aktivitas Sesuai Dengan Harapan, $\mathbf{n}=\mathbf{5 0}$

\begin{tabular}{|c|c|c|c|}
\hline No & $\begin{array}{c}\text { Jawaban } \\
\text { responden }\end{array}$ & $\begin{array}{c}\text { Jumlah } \\
\text { (orang) }\end{array}$ & Persentase \\
\hline 1 & Sangat Puas & 7 & $14 \%$ \\
\hline 2 & Puas & 8 & $16 \%$ \\
\hline 3 & Tidak Puas & 25 & $50 \%$ \\
\hline 4 & Sangat Tidak Puas & 10 & $20 \%$ \\
\hline \multicolumn{2}{|c|}{ Total } & 50 & $100 \%$ \\
\hline
\end{tabular}

Sumber : Hasil olahan kuesioner, 2018

Berdasarkan tabel diatas dapat dianalisis bahwa sebagian besar wisatawan yaitu 7 orang responden dengan persentase $14 \%$ menyatakan sangat puas akan aktivitas di
Bukit Lawang apakah sesuai dengan yang diharapkan, sedangkan 8 orang responden dengan persentase $16 \%$ menyatakan puas akan aktivitas di Bukit Lawang apakah sesuai dengan yang diharapkan, sementara 25 orang responden dengan persentase $50 \%$ menyatakan tidak puas akan aktivitas di Bukit Lawang apakah sesuai dengan yang diharapkan, namun 10 orang responden dengan persentase $20 \%$ menyatakan sangat tidak puas akan aktivitas di Bukit Lawang apakah sesuai dengan yang diharapkan

Tabel 20. Tanggapan Wisatawan Terhadap Kepuasan Pelayanan Di Bukit Lawang, $n=50$

\begin{tabular}{|c|c|c|c|}
\hline No & $\begin{array}{c}\text { Jawaban } \\
\text { responden }\end{array}$ & $\begin{array}{c}\text { Jumlah } \\
\text { (orang) }\end{array}$ & Persentase \\
\hline 1 & Sangat Puas & 5 & $10 \%$ \\
\hline 2 & Puas & 12 & $24 \%$ \\
\hline 3 & Tidak Puas & 26 & $52 \%$ \\
\hline 4 & Sangat Tidak Puas & 7 & $14 \%$ \\
\hline & Total & 50 & $100 \%$ \\
\hline
\end{tabular}

Sumber : Hasil olahan kuesioner, 2018

Berdasarkan tabel diatas dapat dianalisis bahwa sebagian besar wisatawan yaitu 5 orang responden dengan persentase $10 \%$ menyatakan sangat puas akan pelayanan di Bukit Lawang, sedangkan 12 orang responden dengan persentase $24 \%$ menyatakan puas akan pelayanan di Bukit Lawang, sementara 26 orang responden dengan persentase $52 \%$ menyatakan tidak puas akan pelayanan di Bukit Lawang, namun 7 orang responden dengan persentase 14\% menyatakan sangat tidak puas akan pelayanan di Bukit Lawang

Tabel 21. Tanggapan Wisatawan Terhadap Aksesibilitas Menuju Bukit Lawang, $\mathrm{n}=\mathbf{5 0}$

\begin{tabular}{|c|c|c|c|}
\hline No & $\begin{array}{c}\text { Jawaban } \\
\text { responden }\end{array}$ & $\begin{array}{c}\text { Jumlah } \\
\text { (orang) }\end{array}$ & Persentase \\
\hline 1 & Sangat Puas & 2 & $4 \%$ \\
\hline 2 & Puas & 3 & $6 \%$ \\
\hline 3 & Tidak Puas & 35 & $70 \%$ \\
\hline 4 & Sangat Tidak Puas & 10 & $20 \%$ \\
\hline & Total & 50 & $100 \%$ \\
\hline
\end{tabular}

Sumber : Hasil olahan kuesioner, 2018

Berdasarkan tabel diatas dapat dianalisis bahwa sebagian besar wisatawan yaitu 2 orang responden dengan persentase $4 \%$ menyatakan sangat puas akan aksesibilitas menuju Bukit Lawang, sedangkan 3 orang responden dengan persentase $6 \%$ menyatakan puas akan aksesibilitas menuju Bukit Lawang, sementara 35 orang responden dengan persentase $70 \%$ menyatakan tidak puas akan aksesibilitas menuju Bukit Lawang, namun 10 orang responden dengan persentase $20 \%$ menyatakan sangat tidak puas akan aksesibilitas menuju Bukit Lawang

\subsection{Pembahasan Penelitian \\ Berdasarkan hasil}

penyebaran kuesioner yang diberikan kepada wisatawan 
yang melakukan kegiatan trekking di Bukit Lawang. Dapat dianalisis bahwa atraksi wisata yang dapat dilakukan di Bukit Lawang kurang beragam/bervariasi, dan adapun kegiatan utama yang dapat dilakukan di Bukit Lawang hanyalah trekking dengantambahan sebatas memberi makan orangutan. Kegiatan ini dijadikan satu paket wisata trekking yang biasa dilakukan oleh wisatawan mancanegara yang datang berkunjung ke Bukit Lawang. Hal ini ahirnya memperngaruhi motivasi wisatawan yang akan datang ke Bukit Lawang. Adapun beberapa faktor yang mempengaruhi motivasi wisatawan dalam melakukan kegiatan trekking di Bukit Lawang yaitu keseluruhan didasari oleh faktor motivasi (pull factor) faktor penarik dimana terdapat sesuatu yang ingin dilihat dari objek wisata Bukit Lawang. Sementara faktor motivasi (pull factor)/ faktor motivasi pendorong bukanlah menjadi penentu utama dari motivasi wisatawan melakukan kegiatan trekking.

Atraksi wisata dapat dilakukan dengan menambah jalur trekking, dengan memberi variasi durasi waktu trekking, menambah kegiatan rafting dimana sungai yang ada di Bukit Lawang cukup lebar dan memiliki arus yang cukup deras, kegiatan caving dan mengeksplore seluruh keanekaragaman flora dan fauna hutan tropis yang terdapat di Bukit Lawang, sehingga dari sisi atraksi wisata jauh lebih bervariasi.

Faktor motivasi wisatawan untuk melakukan trekking di Bukit Lawang menjadi terlihat bahwa faktor motivasi penarik menjadi hal yang dominan dibandingkan dengan faktor motivasi pendorong. Kekayaan flora dan fauna yang didapat dilihat oleh wisatawan saat melakukan kegiatan trekking dan pusat rehabilitasi orangutan menjadi salah satu nilai lebih yang dimiliki Bukit Lawang dibandingkan dengan objek lain. Dari sisi faktor pendorong, wisatawan lebih datang berkunjung ke Bukit Lawang tanpa tujuan yang khusus, seperti mencari pengetahuan/pembelajaran, pengaktualisasian diri, namun hanya untuk berlibur dan lepas dari kegiatan sehari-hari.

Kepuasan wisatawan terhadap segala aspek yang berhubungan dengan Bukit Lawang baik dari segi pelayanan, aksesbilitas,ketersedian souvenir, kondisi objek dan aktivitas yang dilakukan juga masih dirasa kurang, pihak pengelola dan pemerintah daerah bersama sama dengan sektor swasta dapat bersinergi dan bersama-sama membangun pariwisata di Bukit Lawang. Penciptaan dan pemilihan souvenir khusus Bukit Lawang, aksesibilitas yang terus menerus dijaga sehingga tidak menjadi kendala wisatawan untuk datang berkunjung ke Bukit Lawang.

\subsection{Kesimpulan}

Atraksi wisata bagi wisatawan yang terdapat di Bukit Lawang masih dirasakan kurang beragam/ bervariasi. Atraksi wisata masih fokus di kegiatan Orangutan dan trekking. Walaupun potensi atraksi wisata masih banyak, seperti penambahan durasi trekking, tema dan tujuan trekking yang berbeda dapat menghasilkan keberagaman kegiatan trekking. Atraksi wisata caving, rafting , tubing dan eksplore keanekaragaman hayati (flora\&fauna) yang sangat beragam di Bukit Lawang yang juga merupakan bagian dari Taman Nasional gunung Leuser.

Faktor yang mempengaruhi motivasi wisatawan berkunjung ke Bukit Lawang secara umum masih didominasi oleh faktor penarik (push factor) yang dimiliki oleh wisatawan. Sementara faktor pendorong (push factor) belum menjadi faktor utama dalam melakukan kegiatan trekking. Kepuasan wisatawan dilihat dari aspek kondisi objek wisata, ketersediaan souvenir, aktivitas, pelayanan, aksesibilitas masih belum sesuai dengan harapan dari wisatawan. Hal ini dapat menjadi dampak yang tidak baik bagi Bukit Lawang. Pembenahan, perbaikan dari berbagai aspek harus dilakukan sehingga tidak menutup kemungkinan peningkatan kunjungan wisatawan bahkan meningkatkan kunjungan kembali wisatawan (repeaters). Kerjasama baik dengan masyarakat lokal, pemerintah daerah, para stakeholder menjadi hal yang mutlak agar kepuasan wisatawan bisa meningkat.

\section{Daftar Pustaka}

[1] Arikunto, Suharsimi. (2006). Metodologi Penelitian. Jogjakarta: Bina Aksara.

[2] Chaplin.J.P (2008). Perencanaan Wisata. Bandung: Angkasa.

[3] Kamus Besar Bahasa Indonesia (KBBI)

[4] Kodhyat, H (2013). Sejarah Kepariwisataan \& Perkembangannya di Indonesia, Kementerian Pariwisata dan Ekonomi Kreatif Republik Indonesia untuk LSPPI-Lembaga Study Pengembangan Pariwisata Indonesia., Jakarta.

[5] Marpaung, Happy \& Bahar (2000). Pengetahuan Kepariwisataan,Bandung: Alfabeta.

[6] Fahmi. (2013). Harapan Dan Motivasi Dalam Diri.Jakarta: Wira Mandala. 
[7] Ismayanti. (2005). Pengantar Pariwisata. Jakarta: PT. Grasindo.

[8] Nandi. (2008). Kepariwisatan dan Perjalanan.Jakarta: Rajawali Pers.

[9] I Gusti Bagus Rai Utama. (2011). Pemasaran Pariwisata.Yogyakarta: CV. Andi Offset.

[10] Nuriata. (2014). Paket Wisata.Bandung: Alfabeta.

[11]Oka A. Yoeti. (2002). Pemasaran Pariwisata.Bandung: Angkasa.

[12] Pitana, I Gde, Putu. G. Gayatri. (2005). Sosiologi Pariwisata. Andi, Yogyakarta.
[13] Sadirman. (2001). Interaksi dan Motivasi Belajar-Mengajar. Jakarta: PT. Raja Grafindo Persada.

[14] Sugiyono. (2010). Metode Penelitian Pendidikan Pendekatan Kuantitatif. Alfabeta. Bandung

[15] Susatyo. (2014). Basic Marketing. Yogyakarta: Gosyen Publishing.

[16] Soekadijo. (2000). Anatomi Pariwisata. Jakarta: Gramedia Pustaka utama.

[17]Suryadana. (2013). Sosiologi Pariwisata. Bandung: Humaniora. 